\title{
Penggunaan lemari pengasapan ikan untuk meningkatkan produksi pada industri rumah tangga di Kabupaten Pulau Morotai
}

\author{
Bambang Tjiroso ${ }^{1}$, Rinto M. Nur², Ariestha W. Bustan ${ }^{3}$ \\ ${ }^{1}$ Program Studi Teknik Industri, Unipas Morotai \\ ${ }^{2}$ Program Teknologi Hasil Perikanan, Unipas Morotai \\ ${ }^{3}$ Program Studi Matematika, Unipas Morotai
}

\begin{abstract}
One processed fish product that is fa vored by many people on Morotai Island is smoked fish. Alth ough much popular, the smoked fish home industry on Morotai Island does not routinely produce smoked fish every day. Smoked fish processing still uses conventional equipments. The equipment which is open makes it dif ficult for partners to maximize the use of combustion fumesto smoked fish. Much smoke is wa sted causing the use of fuel waste and smoking time becomes longer a round 4 to 8 hours, so that in one day thepartners only do one smoking process. Besides that, with the condition of smoking equipment that is open in the event of strong win ds or he av y ra in the partner ca nnot carry out the process of smoked fish. The purpose of this community service activities is to replace conventional (open) fish smoking equipment with modern cabinet/cabinet ty pe sm oking equip ment to increa se smoked fish production. The steps taken are the manufacture of smoking equipment, initial testing in ord er to maximize the use of fuel and temperature in the smoking cabinet. The next step is testing the estimated tim e of smoking fish and the capacity of fish in a single production. After the testing phase is completed, it is continued with the socia lization stage for the manufacture and operation of the fish fumecupboard tool to partners as well as the production process assistance. The results of the service show that the amount of fuelneeded is less. In addition, the time needed in one production is fa ster (2-3 hours) and partners can produce smoked fish every day.
\end{abstract}

Key words: smoked fish, tra ditional fish smoking, smoker cabinet, home industry

\section{PENDAHULUAN}

Industri rumah tangga merupakan usaha kerajinan rumah tangga yang mempunyai jumlah pekerja 1 sampai 4 orang. Industri rumah tangga adalah salah satu pendorong perekonomian Indonesia yang banyak digeluti oleh masyarakat karena dapat dilakukan dengan modal yang relatif kecil. Pemilik industri ini biasanya adalah kepala keluarga dan tenaga kerja berasal dari anggota keluarganya sendiri.

Kondisi geografis indonesia yang dikelilingi oleh perairan membuat industri rumah tangga jenis penjualan dan pengolahan ikan memiliki potensi yang sangat besar untuk dikembangkan. Salah satu wilayah di Indonesia yang memiliki potensi tersebut adalah Kabupaten Pulau Morotai. Mata pencaharian utama masyarakatnya yang bekerja sebagai nelayan, membuat kabupaten pulau morotai didominasi oleh industri rumah tangga yang berbasis pada penjualan hasil olahan laut, terutama ikan.

Salah satu produk hasil olahan ikan yang digemari oleh masyarakat Kabupaten Pulau Morotai adalah ikan asap. Ikan asap adalah ikan yang diolah dari proses pengasapan. Pengasapan merupakan teknik melekatkan dan memasukkan berbagai senyawa kimia asap ke dalam bahan pangan (Utomo et al., 2012). Proses pengasapan yang dilakukan di Kabupaten Pulau Morotai bersifat tradisonal, yakni ikan diasapi secara langsung oleh asap yang dihasilkan dari proses pembakaran kayu.

Sebagian besar industri pengasapan ikan di Pulau Morotai mengalami kendala karena alat pengasapan ikan yang mereka miliki masih bersifat konvensional (sistem terbuka). Banyak kelemahan dari alat pengasapan yang bersifat konvensional yang tentunya membuat proses produksi ikan asap sering terhambat. Akibatnya jumlah hasil produksi dan permintaan pasar terhadap ikan asap menjadi 
tidak seimbang. Oleh sebab itu, kegiatan PKMS yang dilakukan yaitu menggantikan alat pengasapan konvensional dengan lemari pengasapan tipe cabinet.

Alat pengasapan yang akan diterapkan dalam pengabdian ini merupakan tipe kabinet atau disebut dengan lemari pengasapan. Dengan menggunakan tempat pengasapan berbentuk lemari yang dapat ditutup rapat, panas dan asap kayu dapat dimanfaatkan dengan sebaikbaiknya (Sulistijowati et al., 2011). Menurut Maripul (2004) penggunaan alat pengasapan sistem tertutup lebih efektif dibandingan dengan penggunaan alat pengasapan sistem terbuka.

\section{METODE PELAKSANAAN}

Pengabdian masyarakat ini dilakukan di tempat industri pengasapaan ikan milik Bapak Arik Rahim di Desa Daruba Pantai, Kecamatan Morotai Selatan, Kabupaten Pulau Morotai. Kegiatan ini dilakukan sejak bulan Juni sampai September 2019.

Pelaksanaan pengabdian ini terbagi dalam beberapa tahap yang diuraikan sebagai berikut:

1. Pembuatan lemari pengasapan ikan: pembuatan lemari pengasapan ikan dilakukan di Laboratorium Fakultas Teknik Universitas Pasifik Morotai. Mitra dilibatkan secara langsung selama tahap pembuatan lemari pengasapan ikan.

2. Sosialisasi program PKMS: Sebelumnya mitra telah bersedia bekerja sama dengan tim PKMS, namun sosialisasi perlu dilakukan karena usaha yang dijalankan mitra adalah usaha keluarga yang melibatkan banyak pihak selain pekerja, seperti isteri, anak, saudara dan sebagainya.

3. Sosialisasi penggunaan lemari pengasapan ikan.

4. Pendampingan proses produksi ikan asap.

\section{PELAKSANAAN DAN HASIL KEGIATAN}

\section{A. Pembuatan Alat Lemari Pengasapan Ikan}

1. Pembuatan rangka dan rak lemari

Pembuatan lemari pengasapan dimulai dari pembuatan rangka lemari dengan ukuran panjang
$120 \mathrm{~cm}$, lebar $80 \mathrm{~cm}$ dan tinggi $200 \mathrm{~cm}$. Bahan yang digunakan dalam pembuatan rangka adalah besi siku dengan ukuran 4 x $3 \mathrm{~cm}$. Tahapan selanjutnya adalah pembuatan rak lemari pengasapan dengan ukuran $110 \times 80 \mathrm{~cm}$ menggunakan Stainless Steel dengan diameter $5 \mathrm{~mm}$.

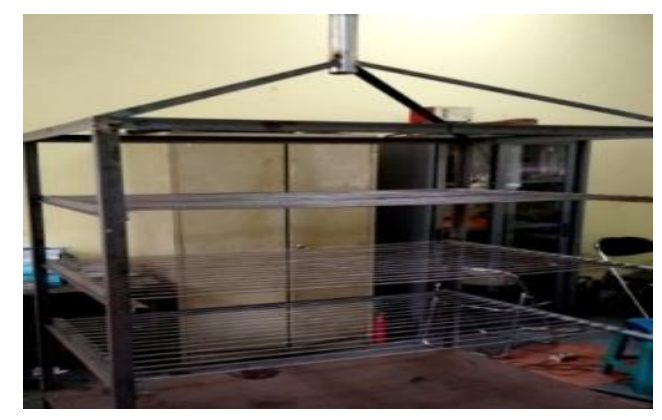

Gambar 1. Rangka dan rak lemari pengasapan

\section{Pembuatan ruang pembakaran}

Ruang pembakaran dibuat menggunakan plat Eser dengan ketebalan 1,6 mm. Plat dipotong menggunakan mesing pemotong kemudian di las berbentuk kotak dengan dimensi panjang $110 \mathrm{~cm}$, lebar $70 \mathrm{~cm}$ dantTinggi $40 \mathrm{~cm}$. Bagian depan bak pembakaran diberi pegangan dari pipa stainless steel sehingga memudahkan saat membuka dan menutup.

Bagian antara ruang pembakaran dan ruang pengasapan dipisahkan oleh sebuah plat. Plat tersebut dilas menyatu dengan rangka lemari dan diberi lubang dengan diameter $19 \mathrm{~mm}$. pembuatan lubang pada plat dilakukan pada seluruh permukaan plat. Hal ini berfungsi untuk asap yang dihasilkan dari ruang pembakaran bisa masuk ke ruang pengasapan dengan merata melalui lubanglubang tersebut.

3. Pemasangan plat aluminium dan roda pada lemari

Proses awal pada tahapan ini adalah memasang plat aluminium pada rangka lemari pangasapan. Plat aluminium diukur kemudian dipotong menggunakan mesin gerinda potong. Plat aluminium yang dipasangkan pada rangka menggunakan paku ripet. Paku ripet berfungsi sebagai perekat antara plat aluminium dan rangka. Setelah plat aluminium dipasang pada rangka, 
selanjutnya dipasang roda pada kaki lemari. Roda berfungsi untuk mempermudah pada saat lemari dipindahkan. Pada posisi diam bagian roda belakang yang dilengkapi pengereman digunakan sehingga lemari tidak dapat bergerak atau bergeser.

4. Pemasangan termometer dan penutup cerobong

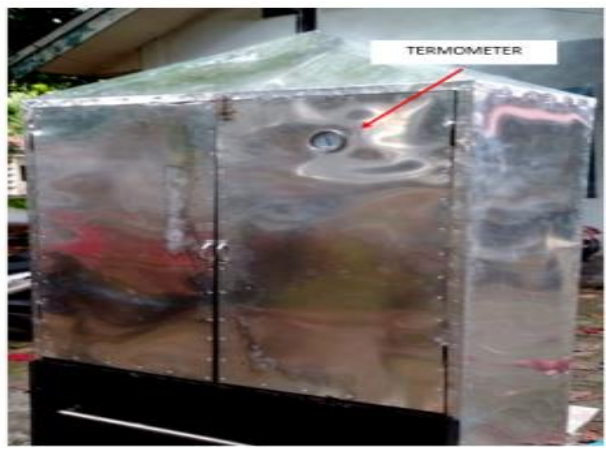

Gambar 2. Lemari pengasapan yang dilengkapi termometer

\section{B. Sosialisasi Program SKS}

Sosialisasi program PKMS kepada perlu dilakukan karena usaha yang dijalankan mitra merupakan yang melibatkan banyak pihak selain pekerja, seperti isteri, anak, saudara dan sebagainya. Sosialisasi yang dilakukan meliputi perkenalan program yang dilakukan tim PKMS, tujuan dan anggota pelaksana. Selain itu, pada kegiatan ini, tim PKMS bersama mitra mengatur waktu untuk kegiatan selanjutnya (sosialisasi penggunaan lemari pengasapan dan penyerahan alat).

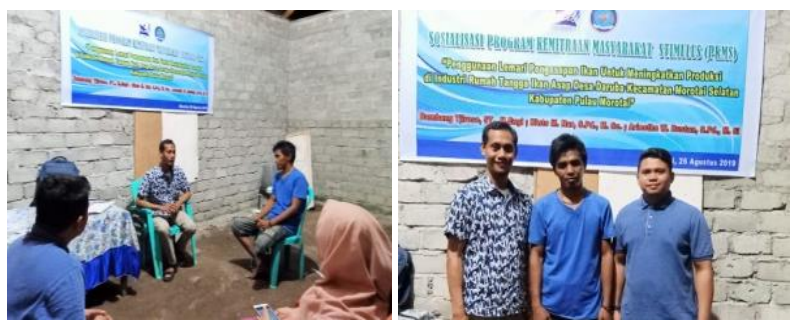

Gambar 3. Sosialisasi Program PKMS kepada mitra

\section{Sosialisasi Penggunaan Lemari Pengasapan dan Pendampingan Produksi}

Tahap sosialisasi dibagi menjadi dua tahap. Tahap pertama dilakukan pemaparan tentang teoriteori yang berkaitan dengan proses pengasapan ikan. Tahap kedua dilakukan pemaparan tentang alat-alat pengasapan ikan sekaligus pelatihan cara pengoperasian lemari pengasapan ikan yang digunakan oleh mitra. Sosialisasi dilakukan bertujuan untuk menambah pengetahuan dan pengalaman mitra terhadap proses pengasapan dan alat yang digunakan pada pengasapan ikan.

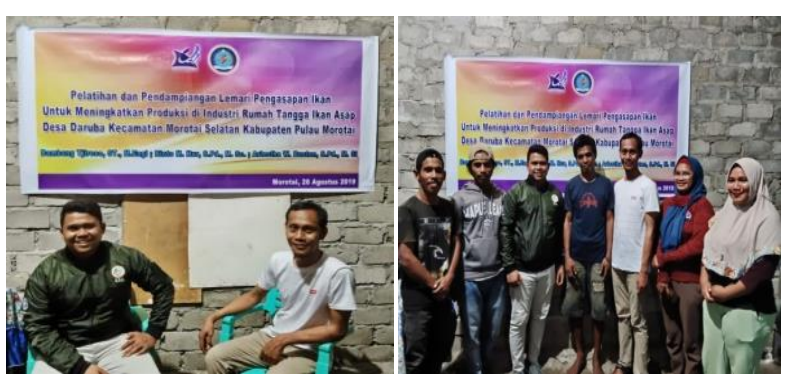

Gambar 4. Tim PKMS melakukan sosialisasi kepada mitra

Tim PKMS juga melakukan pendampingan proses pembuatan ikan asap dengan lemari pengasapan. Pada tahap ini tim PKMS melakukan pendampingan proses pembuatan ikan asap yang dilakukan oleh mitra selama 2 bulan. Hal ini dilakukan untuk mengatasi kendala mitra dalam penggunaan lemari pengasapan sekaligus mengawasi proses produksi ikan asap yang dilakukan oleh mitra.
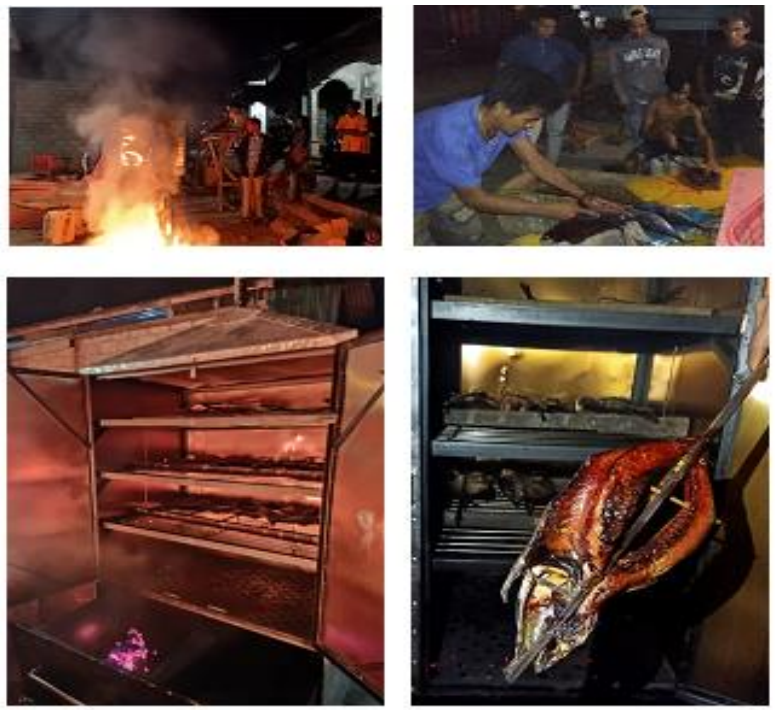

Gambar 5. Pendampingan proses produksi ikan asap menggunakan lemari pengasapan

Penggunaan lemari pengasapan yang dirancang tim PKMS untuk proses produksi ikan asap dapat menghemat bahan bakar dan waktu pengasapan lebih cepat. Sebelumnya mitra menggunakan alat 
yang terbuka sehingga asap mudah terbawa oleh anggin. Hal ini menyebabkan waktu pengasapan lebih lama (4-8 jam dalam sekali produksi). Namun, penggunaan lemari pengasapan, waktu yang dibutuhkan dalam sekali produksi hingga ikan matang sempurna adalah 2-3 jam. Selain itu, pengasapan dengan menggunakan lemari pengasapan lebih higienis karena tertutup sehingga udara dan serangga tidak mudah hinggap ke ikan saat pengasapan.

\section{KESIMPULAN}

Berdasarkan hasil kegiatan PKMS dapat disimpulkan beberapa hal sebagai berikut.

1. Mitra memiliki kemampuan mengoperasikan alat lemari pengasapan.

2. Bahan bakar yang dibutuhkan mitra dalam sekali produksi ikan asap lebih sedikit.

3. Waktu yang dibutuhkan mitra dalam sekali produksi ikan asap lebih singkat.

4. Produk yang dihasilkan lebih higienis karena selama proses pengasapan, ikan terdapat dalam ruag tertutup (lemari).

\section{UCAPAN TERIMA KASIH}

Tim PKMS mengucapkan terima kasih kepada Direktorat Riset dan Pengabdian Masyarakat Kemenristekdikti yang telah memberikan dana kegiatan melalui Program Kemitraan Masyarakat Stimulus (PKMS) tahun 2019. Tim juga mengucapkan terima kasih kepada LPPM Universitas Pasifik Morotai, mitra dan semua pihak yang membantu terselenggaranya kegiatan ini.

\section{DAFTAR PUSTAKA}

Maripul Y. 2004. Mesin Pengasapan Ikan Sederhana. Buletin Teknik Pertanian 9 (1).

Sulistijowati S.R., Djunaedi O.S., Nurhajati J, Afrianto E, dan Udin Z. 2011. Mekanisme Pengasapan Ikan. Bandung: Unpad Press.

Utomo B.S.B., Wibowo S., dan Widianto, T. N. 2012. ASAP CAIR: Cara Membuat \& Aplikasinya Pada Pengolahan Ikan Asap. Penebar Swadaya Grup. 